\title{
Study of the Red Iron Paints for Rubrics and Miniatures: Accelerated Aging and Analytical Data
}

\author{
Aušra ČIULADIENE ${ }^{1}{ }^{*}$, Aldona BEGANSKIENE் ${ }^{1}$, Jūratė SENVAITIENE ${ }^{1,2}$, \\ Aivaras KAREIVA ${ }^{1}$
}

\author{
${ }^{1}$ Institute of Chemistry, Faculty of Chemistry and Geosciences, Vilnius University, Naugarduko st. 24, LT- 03225 Vilnius, \\ Lithuania \\ ${ }^{2}$ Pranas Gudynas Centre for Restoration, Lithuanian Art Museum, Didžioji st. 4, LT 01128, Vilnius, Lithuania \\ crossref http://dx.doi.org/10.5755/j02.ms.25190
}

Received 30 January 2020; accepted 29 May 2020

\begin{abstract}
In this study, the red iron paints used in ancient manuscripts for rubrics and miniatures were fabricated and investigated. The commercial three different iron pigments (red ochre $\left(\mathrm{Fe}_{2} \mathrm{O}_{3}\right)$, red bolus $\left(\mathrm{Fe}_{2} \mathrm{O}_{3} \times \mathrm{SiO}_{2} \cdot \mathrm{Al}_{2} \mathrm{O}_{3}\right)$, and hematite $\left(\mathrm{Fe}_{2} \mathrm{O}_{3}\right)$ ) and three binding media (gum Arabic, fish glue and parchment glue) were used for the preparation of analogous to historical red iron paints. The obtained model red iron paints were analyzed with the aim to create a short data library which could be used for the characterization of different model compositions of red paints as well as real historical and archaeological red paints. The obtained red paints and binding media were characterized using Fourier-transform infrared spectroscopy (FTIR), scanning electron microscopy coupled with energy-dispersive X-ray spectroscopy (SEM/EDX), Xray diffraction (XRD) analysis and thermal (TG/DSC) analysis techniques. The accelerated aging test was also applied for the analogous to historical red iron paints. These results are useful to develop red paint guidelines for the storage and display for improved conservation and accessibility of manuscripts.

Keywords: iron pigments, binders, red iron paints, model compositions, accelerated aging.
\end{abstract}

\section{INTRODUCTION}

The accurate identification of pigments should be done by conservation and restoration scientists and specialists prior the restoration of the object of cultural heritage. Such necessity is related with several reasons. It is very important that the entire recovery will be done with the pigment having the same chemical composition as original rather than a similar shade. The alternative pigments can react with nearby original pigments and irreversible changes occur damaging the painting or other object of restoration. The second reason is necessity to identify any degradation products of pigments and to suspend or cancel proposals for possible treatments that can cause decomposition processes $[1,2]$. In addition, the authenticity of the cultural heritage objects is very important as well. One of the possible ways to check the fake object is to check if the used pigments are in the first production or later period. Moreover, important information on the chemical composition of historical writing inks and paints could be useful for the investigation of various degradation mechanisms of cultural heritage artefacts [3, 4].

Clay and iron oxides were used as artistic pigments in pre-historic times and quickly become very common in all over the world. Clay minerals and iron oxides are closely related to their natural formation [5-7]. Their structural and mineralogical properties are directly related to their natural genesis and origin and help us to explore historical painting techniques and materials of each painting layer which the main building element [8-10]. Paint is the mixture of pigments and binding media, and their composition gives colour quality. The main aspects of this quality are colour stability and coating capacity [11-13]. The colour quality can be highly dependent on the chemical interactions within the mixtures and the surrounding environment. Clay and iron oxides as artistic pigments are found in paintings of each region and at most of the historical periods [14].

If we want to identify an unknown person, we have to compare an unknown fingerprint with one of a specific individual and so know if it was left by that individual. This test method can be described as a "fingerprinting". The study of the materials used for making manuscripts is not so much, probably because the research started in the late eighteenth century [15]. Knowledge of the composition of the original materials and pigments is very helpful for restorers when they have to choose suitable materials and relevant colour tones. The characterization of paint binders in general are in particular is complex due to the sample size, the high inorganic content, the degradation phenomena undergone with time, and the simultaneous presence of other additives $[16,17]$. Therefore, non-invasive analytical techniques have not fully satisfied features and can not be used as a self-consistent analytical tool. The optimal strategy to recognize colourants and other additives used in miniatures or rubrics should, therefore, provide for a multitechnique approach.

This study is a continuous work carried out reconstructing red paints using proteinaceous and natural gums binders aimed to clarify how these materials are aging together and create a short data library which could be used for the characterization of red paints in ancient manuscripts. Nine different analogous to ancient red paints using three

\footnotetext{
${ }^{*}$ Corresponding author. Tel.: +370-5-2193108;

E-mail address: ausra.ciuladiene@chgf.vu.lt (A. Čiuladienė)
} 
red pigment (red ochre, red bolus, hematite) and three binding media (gum Arabic, fish glue, parchment glue) were fabricated in this study. The reconstructed paints before and after artificial aging were then characterized by SEM/EDX, FTIR, XRD, TG/DTG/DSC analysis methods.

\section{EXPERIMENTAL}

\subsection{Materials}

Three different red pigments (red ochre $\left(\mathrm{Fe}_{2} \mathrm{O}_{3}\right.$ ), (11274), red bolus $\left(\mathrm{Fe}_{2} \mathrm{O}_{3}{ }_{\mathrm{x}} \mathrm{SiO}_{2}{ }_{\mathrm{y}} \mathrm{Al}_{2} \mathrm{O}_{3}\right)$, (40503), and hematite $\left.\left(\mathrm{Fe}_{2} \mathrm{O}_{3}\right),(48651)\right)$ and three binding media (gum Arabic (63320), fish glue (63080), and parchment glue (63035)) were purchased from Kremer Pigmente and used for the preparation of red paints. These samples were characterized at first by XRD, SEM/EDX, FTIR, and TG/DTG/DSC analysis. The results of this characterization are already published elsewhere [18].

\subsection{Paints preparation}

A set of pigment-binding media combinations were prepared in the following way. For the preparation of binding media slightly different procedures were used. The parchment and fish glue were washed with distilled water, cut into small pieces and covered with water for $24 \mathrm{~h}$. Next, the glue gently heated $\left(40-50{ }^{\circ} \mathrm{C}\right)$ and stirred for $4 \mathrm{~h}$ till became liquid. Then, $9 \%$ acetic acid (Eurochemicals Reachem) solution was added to the prepared binding media with ratio 1:4. Gum Arabic was fine-cut, covered with distilled water and was left to swell. Then was stirred and filtered through linen fabric. Finally, the glue was mixed with the same concentration solution of acetic acid with ratio $(4: 1)$. The red iron pigments were first ground in an agate mortar with a drop of distilled water and then mixed with the binders resulting in $\sim 85 \mathrm{wt} . \%$ of binding media on a dry-paint composition. Nine different analogous to ancient red paints were fabricated using the compositions of each iron pigment with each binding material. A set of pigmentbinding media combinations were coated on microscope glass slides and dried in the dark. The prepared samples were artificially aged at intervals of 1, 4, 7, 14, 21, 28 and 35 days in a chamber with a constant intensity of UV irradiation of $14887 \mathrm{~mW} / \mathrm{m}^{2}$. Measurements were made using a versatile lux-hygrometer ELSEC 764 UV. The UV source in the aging chamber was the 10-luminescent Osram Eversun L40W/79K fluorescent lamp with a power output of $40 \mathrm{~W}$ ( $400 \mathrm{~W}$ total). Lamps disseminated a wavelength of

$310-400 \mathrm{~nm}$ and are hung $50 \mathrm{~cm}$ above the samples. The temperature in the chamber did not exceed $35^{\circ} \mathrm{C}$ and the relative humidity was $21 \% \mathrm{RH}$ [19].

\subsection{Characterization}

The colour change of the paint was measured with a FLAME-S-VIS-NIR-ES spectrometer with light source HL2000-FHSA $20 \mathrm{~W}$, resolution $\sim 1.5 \mathrm{~nm}$, measuring time $2 \mathrm{~s}$, measuring range $350-1000 \mathrm{~nm}$, used the standard WS-1 Reflectance Standard. The surface morphology of the samples and elemental analysis was studied by the scanning electron microscope coupled with energy dispersive X-ray spectroscopy (SEM/EDX) using Hitachi TM3000 and with the scanning electron microscope (SEM) SU70, $5 \mathrm{kV}$. IR spectroscopy was used for the identification and characterization of functional groups of pigments and binding media in the paint. Infrared spectra were obtained by an FTIR spectrophotometer Perkin Elmer Spectrum TWO with ATR accessory. All spectra were recorded at $4 \mathrm{~cm}^{-1}$ resolution in an interval of $450-4000 \mathrm{~cm}^{-1}$ and 24 scans were accumulated before Fourier transformation. The

X-ray diffraction (XRD) analysis was performed using Benchtop XRD MiniFlex II, Rigaku in the range of 10 to $80^{\circ} 2 \theta, 5 \% \mathrm{~min}$ speed, using $\mathrm{CuK} \alpha_{1}$ radiation. The thermal analysis (TG/DTG/DSC) was recorded using a Perkin Elmer pyris TGA instrument. The heating rate was $10{ }^{\circ} \mathrm{C} / \mathrm{min}$ in air flow from 30 to $900{ }^{\circ} \mathrm{C}$.

\section{RESULTS AND DISCUSSION}

\subsection{Colorimetric measurements}

To investigate the colour stability, the accelerated aging was initially performed on the fabricated red paints [20]. The colour difference $\Delta \mathrm{E}$ in the $\mathrm{CIE}(\mathrm{Lab})^{*}$ system of paints was calculated according to the formula $[19,21,22]$ :

$\Delta E=\left[\left(\Delta L^{*}\right)^{2}+\left(\Delta a^{*}\right)^{2}+\left(\Delta b^{*}\right)^{2}\right]^{1 / 2}$,

where $\Delta L^{*}$ (lightness-darkness difference $)=L^{*}$ aged $-L^{*}$ unaged ; $\Delta a^{*}$ (redness-greenness difference $)=a_{\text {aged }}^{*}-a^{*}$ unaged; and $\Delta b^{*}$ (yellowness-blueness difference $)=b_{\text {aged }}^{*}-b^{*}$ unaged .

Each sample was photographed under the same lighting and at the same height from the sample to capture the appropriate colour. Since the binding media are transparent their photos were made using a white sheet of the paper base. The colour changes of red paints and binding medias before and after accelerated aging are represented in Fig. 1. Visually, the paints fabricated using red ochre exhibit deep red colour independent on the used binding media. However, the paints produced from red bolus and parchment or fish glue have slightly yellowish tint. Red-brownish colour was observed for the paints prepared using hematite pigment. Evidently, the colours of most of the paints have changed after artificial aging.

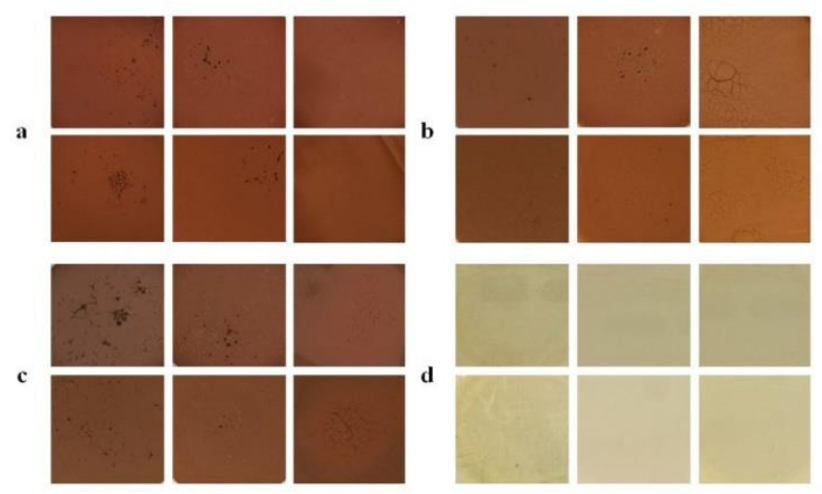

Fig. 1. The digital images of paints fabricated from mixtures: $\mathrm{a}$-red ochre; $\mathrm{b}$-red bolus; $\mathrm{c}$-hematite; with gum Arabic, fish glue and parchment glue (from left to right); $\mathrm{d}$-binding medias, gum Arabic, fish glue and parchment glue before (top) and after 35 days accelerated aging (bottom) 
The paint having the composition of red bolus and parchment glue, probably, had least changes during accelerated aging of paints. The dependence of colour difference $\Delta E$ on accelerated aging time for the parchment glue was mostly affected by artificial aging, while determined $\Delta E$ for the fish glue and gum Arabic are negligible. The results of dependences of colour differences $\Delta E$ for different fabricated paints on accelerated aging time, however, were distributed very widely. The results show that the colour changes during artificial aging are not distributed evenly and are dependent very much on individual composition. All paints, except red bolus with parchment glue, $(\Delta E=0.2)$, were affected by accelerated light temperature and relative humidity. For instance, the red ochre with gum Arabic changed colour at about 11 times, with fish and parchment glue about 2 times. Red bolus with gum Arabic and fish glue changed colour a bit less ( 6-7 times), with parchment glue the colour difference was almost unnoticeable. The colour difference was the same for hematite with all binding media, at about two times higher than the baseline. Note, that a colour difference of $\Delta E \geq 3$ is perceptible to the human eye [23].

\subsection{Scanning electron microscopy (SEM/EDX)}

According to the SEM images, the surface morphology of red paints has changed significantly after 35 days of accelerated aging. The gum Arabic is a complex polysaccharide found as a mixed calcium salt of a polysaccharide acid (Arabic acid) [24]. However, the microstructure of three red paints containing the gum Arabic is quite different. Red bolus and hematite gum Arabic paints are composed of different shape particles of about $50-60 \mu \mathrm{m}$ in size. However, the particles of red bolus show evident tendency to form agglomerates. On the other hand red ochre paint with gum Arabic is composed of smaller mostly spherical particles. It is clearly, that the particle size of all red paints with gum Arabic decreased to 3-20 $\mu \mathrm{m}$ after aging for 35 days. The microstructure of red paints fabricated with fish glue is also mostly determined by used pigment but not by binding media, which like parchment glue is a proteinaceous substance consisting of collagen. The SEM micrograph of composition of hematite and fish glue shows the presence of large microsized particles. When red bolus was used for the preparation of red paints with fish glue the distribution of smaller particles around the large ones is clearly seen. Again, the red ochre paint with fish glue is composed of smaller mostly spherical particles. After artificial aging the particle sizes reduced to approximately of $10 \mu \mathrm{m}$ for all red paints obtained with fish glue. The similar microstructure before and after aging was observed for the red paint samples fabricated with parchment glue. In conclusion, the microstructure of red paints is mostly influenced by the nature of red pigment. In most of the cases the decreasing of particle size of paint components was observed during the artificial aging.

\subsection{FTIR spectroscopy}

FTIR spectra of binding media before and after accelerated aging did not change after artificial aging for 35 days. These results confirm that artificial aging does not destroy chemical composition of gum Arabic, fish glue and parchment glue. The main vibrations attributable to the functional groups of binding media and acetic acid [25] were determined in all three FTIR spectra. In the FTIR spectrum of gum Arabic, the intensive absorption bands at $3300 \mathrm{~cm}^{-1}$ and $1008 \mathrm{~cm}^{-1}$ are characteristic stretching vibrations of the $\mathrm{O}-\mathrm{H}$ bond [26]. The band at $2929 \mathrm{~cm}^{-1}$ is due to characteristic vibrations of $\mathrm{C}-\mathrm{H}$. The absorption band at $1600 \mathrm{~cm}^{-1}$ could be attributed to vibration of the double bond in $\mathrm{C}=\mathrm{O}$. The new absorption band of low intensity was observed at $1727 \mathrm{~cm}^{-1}$ after aging. The FTIR spectra of fish glue and parchment glue are almost identical since the collagen is the main component of these materials. The assignment of absorption bands visible at 3286 and $3266 \mathrm{~cm}^{-1}$ is the same as for gum Arabic. The bands detected at 2945 and $2930 \mathrm{~cm}^{-1}$, from 1480 to $1300 \mathrm{~cm}^{-1}$ could be attributed to $\mathrm{C}-\mathrm{H}$ vibrations. Absorption bands of amides coupled to $\mathrm{C}=\mathrm{O}$ are seen at $1634 \mathrm{~cm}^{-1}$ (amide I), at 1525 and $1535 \mathrm{~cm}^{-1}$ (amide II) and at $1229,1235 \mathrm{~cm}^{-1}$ (amide III) [27]. Thus, the FTIR spectra of binding media samples qualitatively are the same before and after artificial aging. Just the intensity of some absorption bands is slightly different upon the aging of the specimens. The representative FTIR spectra of red paints with various compositions are depicted in Fig. 2.
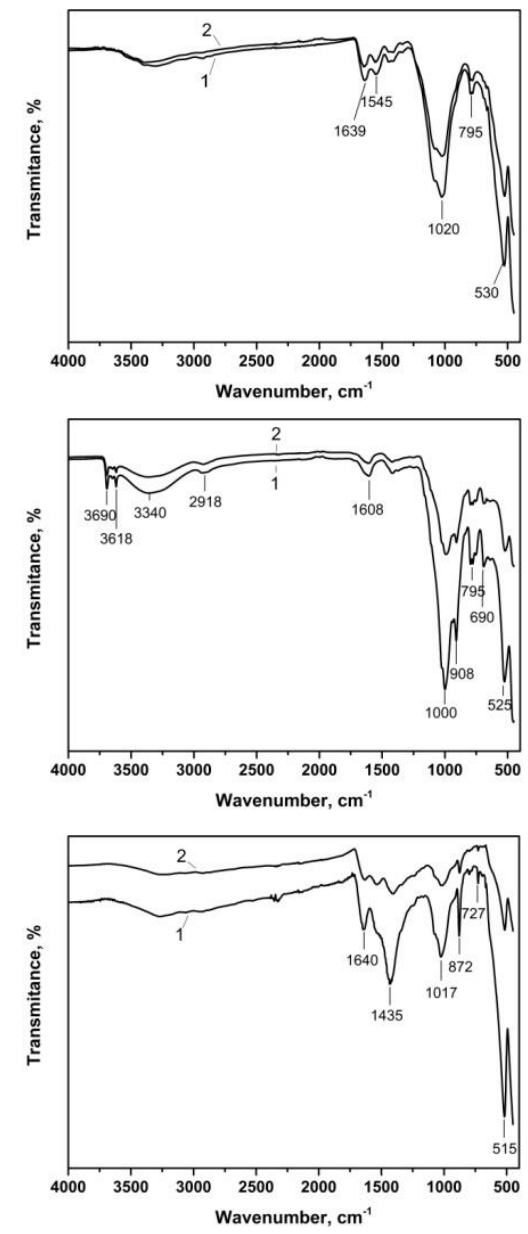

Fig. 2. FTIR spectra of red paint before (1) and after (2) accelerated aging: red ochre with parchment glue (top), red bolus with gum Arabic (middle) and hematite with fish glue (bottom)

In the FTIR spectrum of paint obtained from pigment red ochre with parchment glue the absorption band at 
$1020 \mathrm{~cm}^{-1}$ can be identified as asymmetric $\mathrm{Si}-\mathrm{O}-\mathrm{Si}$ stretching band from silica which is present in commercial red ochre. The band at $795 \mathrm{~cm}^{-1}$ could be attributed to the stretching vibrations of $\mathrm{Si}-\mathrm{O}-\mathrm{Al}$. The intensive absorption band at $530 \mathrm{~cm}^{-1}$ is characteristic $\mathrm{Fe}-\mathrm{O}$ vibration in iron oxide. Absorption bands attributable to the parchment glue are also seen just with decreased intensity. The FTIR spectrum of the red paint fabricated from pigment red bolus and gum Arabic represents all absorption bands characteristic to gum Arabic and additional bands for kaolin $\left(\mathrm{Al}_{2} \mathrm{Si}_{2} \mathrm{O}_{5}(\mathrm{OH})_{4}\right)$. The $\mathrm{O}-\mathrm{H}$ stretching bands are located at 3690 and $3618 \mathrm{~cm}^{-1}$, and asymmetric $\mathrm{Si}-\mathrm{O}-\mathrm{Si}$ stretching band and $\mathrm{Si}-\mathrm{O}$ stretching bands are visible at $1000 \mathrm{~cm}^{-1}$ and $908 \mathrm{~cm}^{-1}$, respectively. The absorption bands determined at 690 and $795 \mathrm{~cm}^{-1}$ are due to $\mathrm{Si}-\mathrm{O}-\mathrm{Al}$ vibrations, and the origin of absorption at $525 \mathrm{~cm}^{-1}$ is $\mathrm{Fe}-\mathrm{O}$ vibrations. The FTIR spectrum of the mixture of hematite and fish glue also shows the characteristic absorption bands of iron oxide at the wavenumbers of $515 \mathrm{~cm}^{-1}$. The absorption bands at $1435 \mathrm{~cm}^{-1}$ and $872 \mathrm{~cm}^{-1}$ are due to vibrations in ionic carbonate $\left(\mathrm{CO}_{3}{ }^{2-}\right)$. Again, the absorption band at $1017 \mathrm{~cm}^{-1}$ could be identified as asymmetric Si-O-Si stretching band [28, 29]. According to the FTIR spectroscopy results, the artificial aging had no any deleterious effect on the fabricated red paints.

\subsection{XRD analysis}

XRD patterns of gum Arabic, fish glue, and parchment glue as was expected, these materials are amorphous and no any crystalline phases could be detected [30-32]. The only one diffraction peak of low intensity at around $2 \theta \approx 23.5^{\circ}$ could be detected in the XRD pattern of fish glue. The exact origin of this diffraction line is unknown. Interestingly, this peak disappeared after artificial aging of material for 35 days. The XRD patterns of binding media samples before and after 35 days of accelerated aging are just slightly different with small shifts of amorphous bumps to various directions.

The XRD patterns of all compositions of red iron paints were without any big differences after aging. The main crystalline phase of the red ochre paint is $\mathrm{Fe}_{2} \mathrm{O}_{3}$ (PDF 00-033-0664), but additional crystalline $\mathrm{Al}_{2} \mathrm{Si}_{2} \mathrm{O}_{5}(\mathrm{OH})_{4}$ phase (at $2 \theta=12.33^{\circ}, 20.98^{\circ}, 68.29^{\circ}$ ) and an impurity of $\mathrm{SiO}_{2}$ phase (at $2 \theta=26.60^{\circ}, 36.37^{\circ}, 37.68^{\circ}$, $45.68^{\circ}, 59.84^{\circ}$ ) are also present in the paint. The XRD patterns of all compositions of red bolus paints were also almost identical before and after aging. Additionally, the paints of red bolus contain three $\mathrm{Fe}_{2} \mathrm{O}_{3}, \mathrm{SiO}_{2}$, and $\mathrm{Al}_{2} \mathrm{Si}_{2} \mathrm{O}_{5}(\mathrm{OH})_{4}$ crystalline phases. The XRD patterns recorded for the hematite paint with and parchment glue before and after aging were almost identical. However, the phase compositions of hematite with fish glue and gum Arabic were slightly different after artificial aging (see Fig. 3). As seen, the paints of hematite also contain diffraction peaks attributable to the impurity $\mathrm{SiO}_{2}$ phase (at $\left.2 \theta=30.74^{\circ}\right)$. Moreover, the diffraction peak at around $2 \theta \approx 23.5^{\circ}$ visible in the XRD pattern of hematite paint with fish glue is not detectable already after artificial aging. This peak probably originates from fish glue. Also, small diffraction line located at about $2 \theta \approx 34.5^{\circ}$ in the XRD pattern of hematite paint with fish glue is not visible anymore after aging.
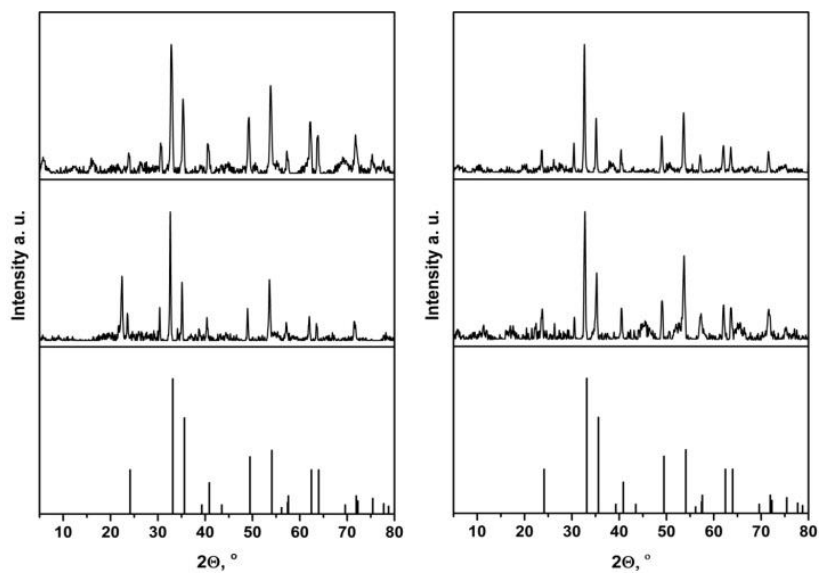

Fig. 3. XRD patterns of hematite paint with fish glue (left) and with gum Arabic (right) before (middle) and after accelerated aging (top) for 35 days. The standard XRD pattern of $\mathrm{Fe}_{2} \mathrm{O}_{3}$ is presented as vertical lines at the bottom

Small changes in the XRD patterns upon aging could be determined in the range of $2 \theta \approx 44-46^{\circ}$ for the hematite and gum Arabic system.

\subsection{Thermal analysis}

Thermal analysis is suitable for the investigation of stability of biological macromolecules presented gum Arabic, fish and parchment glue (polysaccharide and collagen). It was reported, that this method is useful to detect the changes in the biomaterials, such as protein denaturing and aggregation, and degradation during thermal treatment [33]. Fig. 4 shows the TG/DTG/DSC curves of binding media affected by artificial aging for 35 days.

Thermal behaviour of parchment and fish glues is very similar and proceeds via three main decomposition steps. The total mass loss of $100 \%$ was determined for both specimens, however, the full combustion of the fish glue reaches at about $680{ }^{\circ} \mathrm{C}$ and the full decomposition of parchment glue could be achieved at lower temperature $\left(\sim 630^{\circ} \mathrm{C}\right)$. The initial mass loss of these glues (up to $200{ }^{\circ} \mathrm{C}$ ) is associated with broad endotherms and could be attributed to the evaporation of moisture, so-called structurally bound water and decomposition of hydroxyl groups present in the collagen molecule. The main exothermic decomposition proceeds in two steps very similarly for both samples [17, 18, 34-38]. Multistep decomposition with several mass losses could be determined from the TG curve of the gum Arabic. The first mass loss $(\sim 9 \%)$ observed in the temperature range of $30-250{ }^{\circ} \mathrm{C}$ is due to the loss of adsorbed and structural water of gums. The next mass losses of about $89 \%$ at the temperatures $250-450{ }^{\circ} \mathrm{C}, \quad 450-480{ }^{\circ} \mathrm{C}, \quad 480-560{ }^{\circ} \mathrm{C}$, $560-660^{\circ} \mathrm{C}$ is related to the decomposition of polysaccharide and could be also associated with thermal decomposition of intermediate residues formed in carboxymethylated samples with inorganic compounds [18, $39-41]$. As seen, the total mass loss for gum Arabic aged for 35 days is about $98 \%$. 

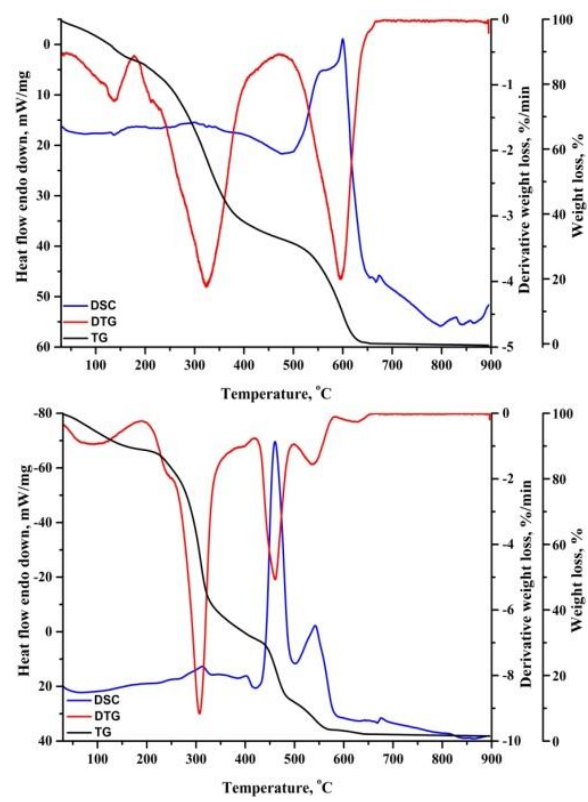

Fig. 4. TG/DTG/DSC curves of binding media affected by artificial aging for 35 days: parchment glue (top) and gum Arabic (bottom).

The TG/DTG/DSC curves of fabricated red ochre, red bolus and hematite paints with selected binding media are presented in Fig. 5.
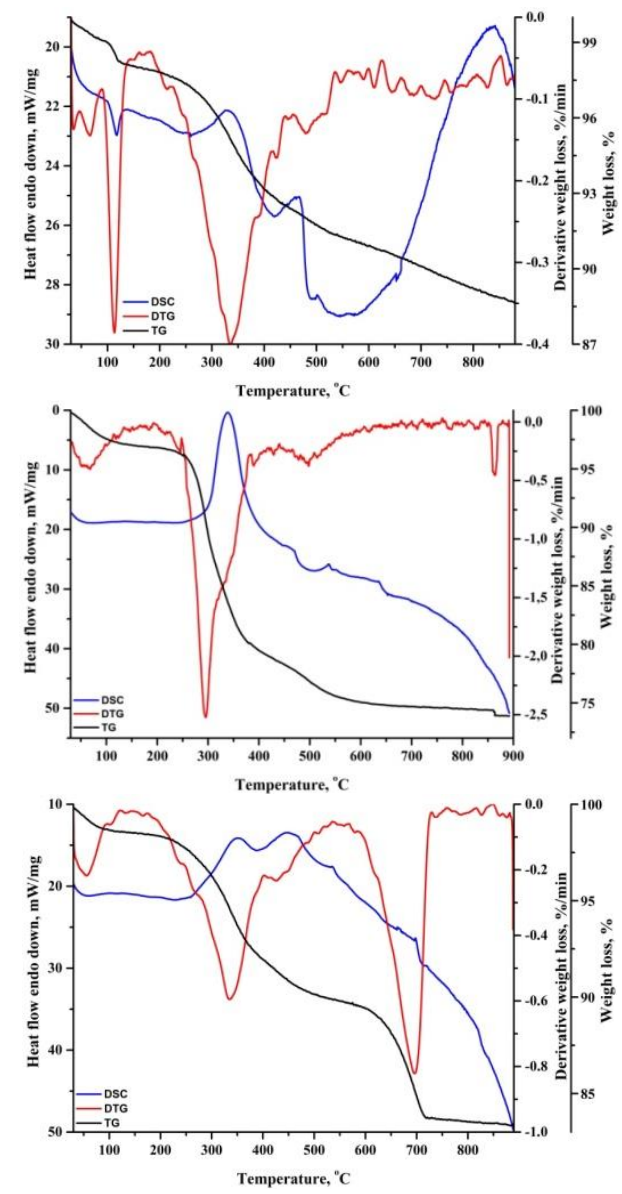

Fig. 5. TG/DTG/DSC curves of different red paints after artificial aging for 35 days: red ochre with parchment glue (top), red bolus with gum Arabic (middle) and hematite with fish glue (bottom)
The main thermal events in these curves correlate very well with those determined for the individual binding media samples. The differences observed in thermal analysis curves for different paints are mainly caused by the presence of different impurities. The red ochre and bolus pigments contain $\mathrm{Al}_{2} \mathrm{Si}_{2} \mathrm{O}_{5}(\mathrm{OH})_{4}$ as impurity phase which decomposes monotonically by heating the sample up to $700-800{ }^{\circ} \mathrm{C}$. Moreover, according to FTIR results the hematite contains also calcium carbonate which decomposes between 600 and $700{ }^{\circ} \mathrm{C}$ [18]. The determined total mass loss varied in the range of $13-26 \%$ depending on the composition of red paints.

\section{CONCLUSIONS}

In this study the red iron paints used in ancient manuscripts were fabricated by combining three different iron pigments (red ochre $\left(\mathrm{Fe}_{2} \mathrm{O}_{3}\right)$, red bolus $\left(\mathrm{Fe}_{2} \mathrm{O}_{3 \times} \mathrm{SiO}_{2}{ }_{\mathrm{y}} \mathrm{Al}_{2} \mathrm{O}_{3}\right)$ and hematite $\left.\left(\mathrm{Fe}_{2} \mathrm{O}_{3}\right)\right)$ with three binding media (gum Arabic, fish glue and parchment glue). The obtained model red iron paints before and after accelerating aging for 35 days have been investigated. Visually, the paints fabricated using red ochre exhibit deep red colour independent on the used binding media. However, the paints produced from red bolus and parchment or fish glue have slightly yellowish tint. Red-brownish colour was observed for the paints prepared using hematite pigment. It was determined that the colours the paints have changed slightly after artificial aging. The composition of red bolus and gum Arabic had least changes during accelerated aging of paints. According to the SEM micrographs, the surface morphology of red paints has changed significantly after 35 days of accelerated aging depending on the nature of red pigment. In most of the cases the decreasing of particle size of paints was observed during the artificial aging. According to the FTIR spectroscopy results, the artificial aging had no any deleterious effect on the fabricated red paints. Thus, the characterization of historical red paints by FTIR spectroscopy along with XRD analysis data would serve valuable information on the initial composition of samples. The thermal analysis of red paints before and after accelerating aging showed that the most thermal events observed in the TG/DTG/DSC curves are related with changes of chemical composition of binding media. In conclusion, it should be emphasized that the most effective identification of historical paints could be done using combination of several characterization methods, including FTIR spectroscopy, X-ray diffraction, SEM/EDX, thermal analyses and specific characterization of colour. Finally, these analytical data can be successfully used to identify iron pigments and corresponding red paints in the ancient manuscripts.

\section{Acknowledgements}

This research was funded by a grant SINALAN (No. SLU-18-13) from the Research Council of Lithuania.

\section{REFERENCES}

1. Clark, R.J.H. Pigment Identification by Spectroscopic means: an Arts/Science Interface Comptes Rendus Chimie 5 2002: pp. 7-20. https://doi.org/10.1016/S1631-0748(02)01341-3 
2. Clark, R.J.H. The Application of Diffuse Reflectance Spectroscopy to Inorganic Chemistry Journal of Chemical Education 41 1964: pp. 488-492. https://doi.org/10.1021/ed041p488

3. Senvaitienè, J., Pakutinskienè, I., Beganskienė, A., Tautkus, A., Kazlauskas, R., Kareiva, A. Destructive Effects of Paper Conservation Procedure on the Writing Iron Gall Ink - Evidence from Transmetalation Reaction Polish Journal of Chemistry 79 2005: pp. 1575-1583.

4. Vanmeert, F., de Keyser, N., van Loon, A., Klaassen, L., Noble, P., Janssens, K. Transmission and Reflection Mode Macroscopic X-ray Powder Diffraction Imaging for the Noninvasive Visualization of Paint Degradation in Still Life Paintings by Jan Davidsz. DeHeem Analytical Chemistry 91 2019: pp. $7153-7161$. https://doi.org/10.1021/acs.analchem.9b00328

5. Opuchovič, O., Kareiva, A. Historical Hematite Pigment: Synthesis by an Aqueous Sol-gel Method, Characterization and Application for the Colouration of Ceramic Glazes Ceramics International 41 2015: pp. 4504-4513. https://doi.org/10.1016/j.ceramint.2014.11.145

6. Kokins, A., Kostjukovs, J., Zarina, L. Natural Iron Oxide (Earth Colour) Deposits in Latvia: an Assessment of the Possibilities for Their Use in Inorganic Pigment Manufacturing Coloration Technology 134 2018: pp. $491-500$. https://doi.org/10.1111/cote.12367

7. Lopes, M.M.S., Alvarenga, R.D.S.S., Pedroti, L.G., Ribeiro, J.C.L., de Carvalho, A.F., Cardoso, F.D., Mendes, B.C. Influence of the Incorporation of Granite Waste on the Hiding Power and Abrasion Resistance of Soil Pigment-based Paints Construction and Building Material 205 2019: pp. $463-474$.

https://doi.org/10.1016/j.conbuildmat.2019.02.046

8. Pottier, F., Gerardin, M., Michelin, A., Hebert, M., Andraud, C. Simulating the Composition and Structuration of Coloring Layers in Historical Painting from Non-invasive Spectral Reflectance Measurements Comptes Rendus Physique 19 2018: pp. 599-611. https://doi.org/10.1016/j.crhy.2018.09.007

9. Lomax, S.Q., Lomax, J.F., Graham, T.K., Moore, T.J. T., Knapp, C.G. Historical Azo Pigments: Synthesis and Characterization Journal of Culture Heritage 35 2019: pp. $218-224$.

https://doi.org/10.1016/j.culher.2018.03.022

10. Nicolopoulos, S., Das, P.P., Perez, A.G., Zacharias, N., Cuapa, S.T., Alatorre, J.A.A., Mugnaioli, E., Gemmi, M., Rauch, E.F. Novel TEM Microscopy and Electron Diffraction Techniques to Characterize Cultural Heritage Materials: From Ancient Greek Artefacts to Maya Mural Paintings Scanning 2019 Art. ID.4870695. https://doi.org/10.1155/2019/4870695

11. Amano, K., Linhares, J.M.M., Nascimento, S.M.C. Color Constancy of Color Reproductions in Art Paintings Journal of the Optical Society of America A: Optics, Image Science \& Vision 35 2018: pp. B324-B333. https://doi.org/10.1364/JOSAA.35.00B324

12. Phan, H.Q., Fu, H.B., Chan, A.B. Color Orchestra: Ordering Color Palettes for Interpolation and Prediction IEEE Transactions on Visualization and Computer Graphics 24 2018: pp. $1942-1955$.

https://doi.org/10.1109/TVCG.2017.2697948

13. Perez-Arantegui, J., Ruperez, D., Almazan, D., Diez-dePinos, N. Colours and Pigments in Late Ukiyo-e Art Works: A Preliminary Non-invasive Study of Japanese Woodblock
Prints to Interpret Hyperspectral Images Using In-situ Pointby-point Diffuse Reflectance Spectroscopy Microchemical Journal 139 2018: pp. 94-109. https://doi.org/10.1016/j.microc.2018.02.015

14. Hradil, D., Grygar, T., Hradilova, J., Bezdička, P. Clay and Iron Oxide Pigments in the History of Painting Applied Clay Science 22 2003: pp. 223-236. https://doi.org/10.1016/S0169-1317(03)00076-0

15. Clarke, M. The Analysis of Medieval European Manuscripts Studies in Conservation 46 2001: pp. 3-17. https://doi.org/10.1179/sic.2001.46.Supplement-1.3

16. Ghezzi1, L., Ducel, C., Bernazzani, L., Bramanti, E., Colombini, M.P., Tine, M.R., Bonaduce, I. Interactions between Inorganic Pigments and Rabbit Skin Glue in Reference Paint Reconstructions Journal of Thermal Analysis and Calorimetry 122 2015: pp. 315-322. https://doi.org/10.1007/s10973-015-4759-x

17. Vieira, M., Nabais, P., Angelin, E.M., Araujo, R., Lopes, J.A., Martin, L., Sameno, M., Melo, M.J. Organic Red Colorants in Islamic Manuscripts (12th-15th c.) Produced in al-Andalus, part 1 Dyes and Pigments 166 2019: pp. $451-459$. https://doi.org/10.1016/j.dyepig.2019.03.061

18. Čiuladienè, A., Luckutè, A., Kiuberis, J., Kareiva, A. Investigation of the Chemical Composition of Red Pigments and Binding Media Chemija 29 2018: pp. 243-256. https://doi.org/10.6001/chemija.v29i4.3840

19. Ragauskienė, D., Makuška, R. Consolidation and Ageing Features of Vinylneodecanoatecontaining in Adhesive Films Used as a Support for Museum Textiles Chemija 17 2006: pp. $52-59$.

20. Feller, R.L. Accelerated Aging: Photochemical and Thermal Aspects. Marina del Rey, CA: Getty Conservation Institute, 1994.

21. Opuchovič, O., Kreiza, G., Senvaitienè, J., Kazlauskas, K., Beganskiené, A., Kareiva, A. Sol-gel Synthesis, Characterization and Application of Selected Submicrosized Lanthanide ( $\mathrm{Ce}, \mathrm{Pr}, \mathrm{Nd}, \mathrm{Tb})$ Ferrites Dyes and Pigments 118 2015: pp. 176-182. https://doi.org/10.1016/j.dyepig.2015.03.017

22. Gražènaitė, E., Jasulaitienè, V., Senvaitienė, J., Ramanauskas, R., Kareiva, A. Sol-gel Synthesis, Characterization and Application of Lanthanide-doped Cobalt Chromites $\left(\mathrm{CoCr}_{2-\mathrm{x}} \mathrm{Ln}_{\mathrm{x}} \mathrm{O}_{4} ; \quad \mathrm{Ln}=\mathrm{Tm}^{3+}\right.$ and $\left.\mathrm{Yb}^{3+}\right)$ Journal of the European Ceramic Society 38 2018: pp. 3361-3368.

https://doi.org/10.1016/j.jeurceramsoc.2018.03.038

23. Elert, K., Herrera, A., Cardell, C. Pigment-Binder Interactions in Calcium-based Tempera Paints Dyes and Pigments 148 2018: pp. 236-248. https://doi.org/10.1016/j.dyepig.2017.09.013

24. Sanchez, C., Nigen, M., Tamayo, V.M., Doco, T., Williams, P., Amine, C., Renard, D. Acacia Gum: History of the Future Food Hydrocolloids 78 2018: pp. $140-160$. https://doi.org/10.1016/j.foodhyd.2017.04.008

25. Kroustallis, S. Binding Media in Medieval Manuscript Illumination: a Source Research Revista de História da Arten, Serie W 1 2011: pp. 105-117.

26. Don, Y., Sørensen, K.M., He, S., Balling Engelsen, S. Gum Arabic Authentication and Mixture Quantification by Near Infrared Spectroscopy Food Control 78 2017: pp. $144-149$. https://doi.org/10.1016/j.foodcont.2017.02.002 
27. de Campos Vidal, B., Mello, M.L.S. Collagen Type I Amide I Band Infrared Spectroscopy Micron 42 2011: pp. 283-289. https://doi.org/10.1016/j.micron.2010.09.010

28. Jonynaitè, D., Senvaitienè, J., Beganskienė, A., Kareiva, A. Spectroscopic Analysis of Blue Cobalt Smalt Pigment Vibrational Spectroscopy 52 2010: pp. $158-162$. https://doi.org/10.1016/j.vibspec.2009.12.005

29. Vila, A., Garcia, J.F. Analysis of the Chemical Composition of Red Pigments and Inks for the Characterization and Differentiation of Contemporary Prints Analytical Letters 45 2012: pp. 1274-1285. https://doi.org/10.1080/00032719.2012.673100

30. Niu, F., Kou, M., Fan, J., Pan, W., Feng, Z., Su, Y., Yang, Y., Zhou, W. Structural Characteristics and Rheological Properties of Ovalbumin-gum Arabic Complex Coacervates Food Chemistry 260 2018: pp. 1-6. https://doi.org/10.1016/j.foodchem.2018.03.141

31. Davidenko, N., Campbell, J.J., Thian, E.S., Watson, C.J., Cameron, R.E. Collagen-hyaluronic Acid Scaffolds for Adipose Tissue Engineering Acta Biomaterialia 6 2010: pp. 3957-3968. https://doi.org/10.1016/j.actbio.2010.05.005

32. Wang, K., Wang, W., Ye, R., Liu, A., Xiao, J., Liu, Y., Zhao, Y. Mechanical Properties and Solubility in Water of Corn Starch-collagen Composite Films: Effect of Starch Type and Concentrations Food Chemistry 216 2017: pp. 2009-2016. https://doi.org/10.1016/j.foodchem.2016.08.048

33. Fessas, D., Signorelli, M., Schiraldi, A., Kennedy, C.J., Wess, T.J., Hassel, B., Nielsen, K. Thermal Analysis on Parchments I: DSC and TGA Combined Approach for Heat Damage Assessment Thermochimica Acta 447 2006: pp. 30-35. https://doi.org/10.1016/j.tca.2006.04.007

34. Sebestyén, Z., Czégény, Z., Badea, E., Carsote, C., Şendrea, C., Barta-Rajnai, E., Bozi, J., Miu, L., Jakab, E. Thermal Characterization of New, Artificially Aged and
Historical Leather and Parchment Journal of Analytical and Applied Pyrolysis 115 2015: pp. 419-427. https://doi.org/10.1016/j.jaap.2015.08.022

35. Tomassetti, M., Marini, F., Campanella, L., Coppa, A. Study of Modern or Ancient Collagen and Human Fossil Bones from an Archaeological Site of Middle Nile by Thermal Analysis and Chemometrics Microchemical Journal 108 2013: pp. 7-13. https://doi.org/10.1016/j.microc.2012.11.006

36. Axelsson, K.M., Larsen, R., Sommer, D.V.P. Dimensional Studies of Specific Microscopic Fibre Structures in Deteriorated Parchment Before and During Shrinkage Journal of Culture Heritage 13 2012: pp. 128-136. https://doi.org/10.1016/j.culher.2011.08.001

37. Budrugeac, P., Badea, E., Della Gatta, G., Miu, L., Comănescu, A. A DSC Study of Deterioration Caused by Environmental Chemical Pollutants to Parchment, a Collagen-based Material Thermochimica Acta 500 2010: pp. $51-62$. https://doi.org/10.1016/j.tca.2009.12.010

38. Riccardi, A., Mercuri, F., Paoloni, S., Zammit, U., Marinelli, M., Scudieri, F. Parchment Ageing Study: New Methods Based on Thermal Transport and Shrinkage Analysis e-PS 7 2010: pp. 87-95.

39. Jamaludin, J., Adam, F., Rasid, R.A., Hassan, Z. Thermal Studies on Arabic Gum - Carrageenan Polysaccharides Film Chemical Engineering Research Bulletin 19 2017: pp. $80-86$. https://doi.org/10.3329/cerb.v19i0.33800

40. Daoub, R.M.A., Elmubarak, A.H., Misran, M., Hassan, E.A., Osman, M.E. Characterization and Functional Properties of Some Natural Acacia Gums Journal of the Saudi Society of Agricultural Sciences 17 2018: pp. $241-249$. https://doi.org/10.1016/j.jssas.2016.05.002

41. Silva, D.A., Feitosa, J.P. A., Maciel, J.S., Paula, H.C.B., de Paula, R.C.M. Characterization of Cross Linked Cashew Gum Derivatives Carbohydrate Polymers 66 2006: pp. $16-26$. https://doi.org/10.1016/j.carbpol.2006.02.021 License (http://creativecommons.org/licenses/by/4.0/), which permits unrestricted use, distribution, and reproduction in any medium, provided you give appropriate credit to the original author(s) and the source, provide a link to the Creative Commons license, and indicate if changes were made. 